\title{
Models of Professional Career of the Managerial Woman*
}

\section{Modelos de carrera profesional de la mujer directiva}

Recibido: marzo 4 de 2013 | Revisado: junio 1 de 2013 | Aceptado: agosto 15 de 2013

\author{
Clara Selva Olid ** \\ Autonomous University of Barcelona, Spain
}

Doi: 10.11144/Javeriana.UPSY12-4.mopc

Para citar este artículo: Selva, C. (2013). Models of professional career of the managerial woman. Universitas Psychologica, 12(4), 1237-1254. Doi: 10.11144/ Javeriana.UPSY12-4.mopc

* Acknowledgements: Special thanks to Dr. Miguel Angel Sahagún Padilla and Dra. Susana Pallarès Parejo for their help, effort and enthusiasm.

* Professor at the Autonomous University of Barcelona, where she teaches and conducts research in areas related to organizational psychology and psychology of work. Universitat Autónoma de Barcelona.E-mail: Clara.selva@uab.cat

\begin{abstract}
A B S T R A C T
In recent years the professional trajectory of women and their access to management positions has earned relevance in the literary corpus. The aim of this work is to describe the professional trajectories that characterize the evolution towards management. The study is based on a series of open-ended, semi-structured interviews that were subjected to a systematic, interpretive analysis using a phenomenological, longitudinal approach. The analysis perspective is based on life stories, by means of a declaration or story about the last 12 years of nine women's careers. These stories reveal the events, lived and told, which characterize the professional trajectory where they occur. The results show 4 career models as a way of analyzing the professional trajectories.

Key words author

Woman, gender, professional trajectory, transitions, management, career models, longitudinal approach, life stories, accounts.

Key words plus

Critical Social Psychology, Gender Policy, Qualitative Research.
\end{abstract}

\section{RES UMEN}

En los últimos años la trayectoria profesional de la mujer y su acceso a cargos de responsabilidad ha ido ganado relevancia en el corpus literario. El objetivo de este trabajo es, precisamente, describir las trayectorias que caracterizan el paso a la dirección. El estudio se basa en una serie de entrevistas abiertas, semiestructuradas, que fueron sometidas a un análisis interpretativo, sistemático y con un enfoque fenomenológico y longitudinal. La perspectiva de análisis se orienta por las historias de vida, mediante relatos de los doce últimos años de carrera de nueve mujeres. Estas historias revelan los acontecimientos que se viven y se relatan y que caracterizan la trayectoria profesional. Los resultados muestran cuatro modelos de carrera como una forma de analizar las trayectorias profesionales.

Palabras claves autor

Mujer, género, trayectoria profesional, transición, dirección, modelos de carrera, aproximación longitudinal, historias de vida, relatos.

Palabras clave descriptores

Psicología social crítica, políticas de género, investigación cualitativa. 


\section{Introduction}

One of the most important developments in recent decades, the progressive access of women to the labour market, has altered the traditional concept of working structures (López, 2007). Evidence proves these transformations in the labour market, such as women's increasing working life and their access to technical and skilled jobs (Godoy \& Mladinic, 2009). Nevertheless, society has not been able to eliminate the traditional link between power and gender, which rules the working world (Ramos, Barberà, \& Sarrió, 2003).

Despite the measures launched by the government and other institutions, most management positions are still occupied by men (López \& García-Retamero, 2009) and the organising identities and cultures continue to be mainly ruled by men (Simpson, 2000; Wajcman, 1998; Wajcman \& Martin, 2002). This article presents some of the studies on women's access to management that have characterised the path from the 1970s to date. This will serve as a framework to assess the main obstacles that women have faced, and continue to face as a barrier to accessing management positions. Through these obstacles, a common form of the notion of a professional career can be highlighted.

The professional trajectory and the transitions it comprises provide an exceptional scenario to identify the network of conditions that hinder or facilitate women's access to management. The aim of this work is, precisely, to describe, from a gender perspective, the professional trajectories that characterize the move of women from middle management to management, as well as the transitional phases that make these possible.

\section{Gender Research and Access to Management}

Discrimination seems to be the most common argument in the literary corpus, underlining the need to deal with gender when analysing the work-related environment, and showing that for decades, the division of work according to gender has been seen as a natural result of men and women's role in the biological reproduction of the human species ( $\mathrm{Ra}$ mos et al., 2003). Research on gender carried out throughout the seventies began to consider professional relationships as asexual, (Ramos et al., 2003), provoking concern regarding working segregation, its evolution, and the existence of such segregation of employees and trade unions throughout the eighties (Wajcman, 1998). Research in the nineties emphasised the importance of taking the organisation of such diversity seriously in order to understand the business framework. In later research, Kelan (2009) put forward an argument about the neutrality of the workplace and discrimination, suggesting that work places are allocated regardless of employees' gender. Today, the gender analysis related to the world of work focuses mainly on the description of gender discrimination; moreover, it aims to develop theories on the barriers preventing women from entering and being promoted in the working world. It also provides us with alternative proposals for change and some ways to reach the established goals (Ramos et al., 2003).

In the literary corpus, the barriers concerning women's access to management, within the frame of the aforementioned research, have been diverse. Thus, research in the seventies put forward theories based on gender inequality, related to the law of attraction, supporting the fact that individuals feel attracted to those who are similar to themselves (Tharenou, 1999). Therefore, in a society in which most managers are men, these prefer other men to occupy their positions, rather than women, demonstrating homosocial reproduction. Later on, other research suggests that a lack of human capital (seen as the difference between genders and knowledge) and a lack of social capital (lack of support and exclusion of social stereotypes) are hindrances to achieving a transition towards positions that require more responsibility.

The latest research is based on four assumptions (Selva, Sahagún, \& Pallarès, 2011). The first, the 'lacking theory', claims that women lack the work experience needed, (Heilman, 2001). The second claims that women are not interested or motivated enough to occupy these positions, suggesting that they have an altruist-affective concept 
of work (Hola \& Todaro, 1992; Pratto, Stallworth, Sidanius, \& Siers, 1997). The third is concerned with the existence of several internal inhibitors, often unconscious, that restrain women's access to management, (Anca \& Aragón, 2007). The last hypothesis states that rather than lacking interest in positions of responsibility, women are faced with more limitations (Eagly \& Carli, 2007).

While research has been focused on specific barriers and the way these are perceived, both from an empirical and theoretical perspective, such as stereotypes, (Baron \& Byrne, 2005; Dickman \& Eagly, 2000), other important factors of traditional research have been forgotten, such as the access to higher education (Anca \& Aragón, 2007; Pallarès \& Martínez, 1993; Selva, Pallarès, \& Sahagún, 2013). However, these explanations underline the importance of education and learning through the 'hidden curriculum', which refers to the beliefs, rules and social values that are not found among academic aims and goals, but are efficiently transmitted through imitation and interiorisation of mechanisms (Bonilla \& Martínez, 1992).

Other research focuses on the new barriers to promotion. Widening the concept of the 'glass ceiling', we discover the concept of the 'glass wall', referring to the obstacles women encounter on their path when they are chosen to perform expatriated positions, (Linehan, 2000), increasingly becoming an integral part in the development of their access to management (Hartl, 2004); or illustrating, using the graphic icon of the labyrinth, (Eagly \& Carli, 2007) the problems women have to face. This fact shows that, rather than an invisible and subtle restraint, close to a specific post near the highest positions in the professional hierarchy, hindrances are multiple throughout the different stages of their working life, and they are not invisible. Prejudices towards the interests that influence their careers and their presence in management positions are widespread, mainly mentioning their family responsibilities and women leadership (Godoy \& Mladinic, 2009).

The discourse of women who carry out management tasks supports the last hypothesis, pointing out that one of the worst hindrances to them achieving high positions is the fact that they are still responsible for family life (Godoy \& Mladinic, 2009). Eagly and Carli (2007) state that family life demands cause women to interrupt their careers and it becomes more likely for them to work parttime, leading to less working experience and fewer working hours per year, compared to men. This fact means that their professional careers advance more slowly, reducing their income and their time to establish professional frameworks, which may be decisive for the progress of their professional life. Therefore, the main problem is not exactly about their lack of interest in occupying positions with responsibility, but the amount of limitations and restraints they have to undergo. In this research, gender will be taken as a social and cultural construction to which a certain type of skills, attitudes and roles are ascribed, according to the social significance that we derive from sexual differentiation among human beings (De Beauvior, 2000). Being like that, the aforementioned phenomena, the specificity of the obstacles and constraints in women's career trajectories and the need to address not only the visible discriminations or institutional statements, but also the social processes that create identities, preferences and expectations specific for women and men, underline the need to explore the professional trajectories in terms of gender (Selva \& Vitores, 2013). Mainstream gender in research in the workplace let us explain the relationships of domination and exploitation that occurs in social relationships and interpret how the power comes to them (Berbel, 2013).

Amongst the different approaches studied, the concept of trajectory is underlined. In general terms, it refers to the different stages followed by an individual after accomplishing his/her training to perform a specific job or to take part in professional activities, in professional, economic and social terms (Jiménez, 2009). The professional trajectories of individuals show us, through their actions, how they develop their specific activities, the physical positions of their jobs, the role of organisations and of institutions and companies, the different kinds of jobs performed and how they use their income, as well as the way these individuals deal with the 
capital, according to Bourdieu (1997), of social and cultural heritage (Buontempo, 2000), and the organisations that support them in their access to the labour market (Jiménez, 2009).

Professional trajectories are characterised by stages of stability or instability, which establish the progress or standstill they are undergoing, and which are also useful to determine their continuity or discontinuity (Buontempo, 2000; Jiménez, 2009). In recent decades, since entering into a more industrialised society, characterised by constant changes and great uncertainty, trajectories tend to be more fragmented, discontinuous and diverse than in the past. The sequence of stages making up the trajectory come after transformations, and are highly conditioned by the training carried out and the combination of both micro and macrosocial factors (such as family precedents, personal relationships, gender or labour market conditions) (Jiménez, 2009). Therefore, we can assume that the trajectory mentioned ranges between the historical and social space in which social positions or roles follow one another thanks to transitions (Boado, 1996), and require some restructuring of the heritage capital itself (Buontempo, 2000; Fernández, 2002).

In this sense, career transition means the transition from one activity, division, occupation, industry or organisation to another, so it can lead to a change in the physical location and/or occupation of a person, a change in the wills and professional expectations thereof, or a change in both directions. Following this literature, Latack (1984) identifies three typologies of physical and/or professional transition: a) the intra organisational transitions, in which you move from one division to another within the same organisation, b) the inter organisational transitions, in which you move from one organisation to another, and c) the inter professional transitions, which refer to a change in the occupation. While other classifications, such as the Encyclopedia of Career Development (2006), focus in the change of the person and their wills, identifying transitions: a) arising out of personal dissatisfaction, b) driven by more attractive career options, and/or c) due to changes in the professional interests.
A theoretical overview of women's access to management has been presented, as well as the positions and results of the research carried out, and the notion of the professional trajectory has been highlighted. In this context, the need to identify the different events experienced and related is set out; the events, and more specifically the transitions that make up the professional trajectory and the career stages in which they occur, all from the perspective of the meanings, which render them intelligible for its protagonists. This analysis will lead us to visualise career models, which enable the professional trajectory to be read from a gender perspective.

\section{Method}

The study is based on a series of open-ended, semistructured interviews that were subjected to a systematic, interpretive analysis using a phenomenological, longitudinal approach. Nine women with experience in middle management positions in private and public organisations participated in the study. Each of the study participants was interviewed twice over a span of 12 years. The first series of interviews was conducted in 1998, while the second was conducted in 2010. The interviews focused on the professional careers of the interviewees, highlighting events and career-related expectations. Both series of interviews were held in Barcelona, where these women lived and worked during those years. Transversally, all of them belong to the middle social class, a fact that is reflected in their stories and in the contexts (social and personal) that surround the events and phases that characterize their professional development. Therefore, in terms of this social characteristic, the sample is homogeneous. The characteristics of the sample agents can be found in Table 1 .

The first series of interviews, the results that are reported in Martínez and Pallarès (2000), covered topics such as opportunities and constraints for career development, the experience of being women in middle management positions, work-family balance issues, and expectations regarding the possibility of occupying a top management position. The script 
TABLE 1

Characteristics of the sample agents

\begin{tabular}{|c|c|c|c|c|c|c|}
\hline \multicolumn{7}{|c|}{ Sample Characteristics } \\
\hline & Case & Organisation Typology & Territorial area & Industry growth & Position & Family conditions \\
\hline \multirow{2}{*}{1} & 1998 & International & Private & \multirow{2}{*}{ Stability } & \multirow{2}{*}{$\begin{array}{c}\text { Middle } \\
\text { Management }\end{array}$} & Married \\
\hline & 2010 & State & Public & & & Married, with a child \\
\hline \multirow{2}{*}{2} & 1998 & \multirow{2}{*}{ International } & \multirow{2}{*}{ Private } & Expansion & $\begin{array}{c}\text { Middle } \\
\text { Management }\end{array}$ & Single \\
\hline & 2010 & & & Recession & $\begin{array}{c}\text { Middle } \\
\text { Management }\end{array}$ & $\begin{array}{l}\text { Single, with a } \\
\text { daughter }\end{array}$ \\
\hline \multirow{2}{*}{3} & 1998 & \multirow{2}{*}{ National } & \multirow{2}{*}{ Private } & Expansion & $\begin{array}{c}\text { Middle } \\
\text { Management }\end{array}$ & $\begin{array}{l}\text { Divorced, with a } \\
\text { child }\end{array}$ \\
\hline & 2010 & & & Stability & $\begin{array}{c}\text { Middle } \\
\text { Management }\end{array}$ & $\begin{array}{l}\text { Divorced, with a } \\
\text { child }\end{array}$ \\
\hline \multirow{2}{*}{4} & 1998 & \multirow{2}{*}{ Regional } & \multirow{2}{*}{ Public } & Stability & $\begin{array}{c}\text { Middle } \\
\text { Management }\end{array}$ & $\begin{array}{l}\text { Married, with two } \\
\text { children }\end{array}$ \\
\hline & 2010 & & & Recession & $\begin{array}{c}\text { Middle } \\
\text { Management }\end{array}$ & $\begin{array}{c}\text { Married, with two } \\
\text { children }\end{array}$ \\
\hline \multirow{3}{*}{5} & 1998 & \multirow{3}{*}{ International } & \multirow{3}{*}{ Private } & Expansion & $\begin{array}{c}\text { Middle } \\
\text { Management }\end{array}$ & Married \\
\hline & & & & & & \\
\hline & 2010 & & & Recession & Management & Married, with a child \\
\hline \multirow{2}{*}{6} & 1998 & \multirow{2}{*}{ International } & \multirow{2}{*}{ Private } & Expansion & $\begin{array}{c}\text { Middle } \\
\text { Management }\end{array}$ & Married, with a child \\
\hline & 2010 & & & Recession & $\begin{array}{l}\text { Position without } \\
\text { responsibility }\end{array}$ & $\begin{array}{l}\text { Married with three } \\
\text { children }\end{array}$ \\
\hline \multirow{2}{*}{7} & 1998 & \multirow{2}{*}{ International } & \multirow{2}{*}{ Private } & Expansion & $\begin{array}{c}\text { Middle } \\
\text { Management }\end{array}$ & $\begin{array}{l}\text { Married with a } \\
\text { daughter }\end{array}$ \\
\hline & 2010 & & & Recession & Management & $\begin{array}{c}\text { Married, with a } \\
\text { daughter }\end{array}$ \\
\hline \multirow{2}{*}{8} & 1998 & \multirow{2}{*}{ Regional } & \multirow{2}{*}{ Public } & Expansion & $\begin{array}{c}\text { Middle } \\
\text { Management }\end{array}$ & $\begin{array}{l}\text { Married with a } \\
\text { daughter }\end{array}$ \\
\hline & 2010 & & & Recession & $\begin{array}{l}\text { Position without } \\
\text { responsibility }\end{array}$ & $\begin{array}{c}\text { Married with a } \\
\text { daughter }\end{array}$ \\
\hline \multirow{2}{*}{9} & 1998 & \multirow{2}{*}{ Regional } & \multirow{2}{*}{ Public } & Stability & $\begin{array}{c}\text { Middle } \\
\text { Management }\end{array}$ & $\begin{array}{l}\text { Married with three } \\
\text { children }\end{array}$ \\
\hline & 2010 & & & Recession & $\begin{array}{l}\text { Position without } \\
\text { responsibility }\end{array}$ & $\begin{array}{l}\text { Widow, with three } \\
\text { children }\end{array}$ \\
\hline
\end{tabular}

Source: Own work.

of the second series of interviews maintained the same script contents as that used in the first series, adding topics regarding the contrast between career expectations in 1998 and the actual events defining their trajectories from 1998 to the present day. Both scripts, the 1998 version and its 2010 counterpart, sought to explore the experiences and feelings lived by participants regarding major breakthroughs and setbacks throughout their careers. Before the second series of interviews was held, considerable efforts were made to make contact with participants 12 years after the original study. Most of the 
participants were working in different companies, had changed their residence or had retired or left their workplace due to health issues. Nevertheless, the efforts proved worthwhile. The authors of this study managed to contact and interview eight out of ten of the original participants. Both interviews, 1998 and 2010, lasted an average of 40 minutes and were taped and transcribed verbatim.

The phenomenological-longitudinal approach followed in this study has many particular features. Firstly, phenomenological and longitudinal concerns are mostly derived from some guidelines of the life stories method. Life stories seek to grasp the links between identity and practice, between individuals and their social settings, between major trends and idiosyncratic features across time. Using some notions of this method we can understand and discover the daily work of these agents as well as the practices that make up their trajectories; practices that, in turn, will allow us to explore the world of its values, its representations and subjectivities in depth (Mallimaci \& Giménez, 2006). The experiences of the agents will be used to build the main features of their professional career (Mallimaci \& Giménez, 2006); formed at different times in a stable or fragmented way, or in the form of stopping and re-starting over time (Galindo, 1997). This will enable us to discover a social reality through accounts from the agents themselves.

The analytic procedure sought to transfer that selection of guidelines from the life stories method into a procedure that could be systematically applied to the set of interviews. The interpretation of the interviews responded to the different events and phases experienced by each participant during their trajectory. In other words, the interviews were read from the perspective of the events $(\mathrm{E} 1, \mathrm{E} 2, \mathrm{E} 3 \ldots)$ and phases (P1, P2, P3 ...) comprising the trajectory. The identification and definition of each event or phase was based on what these meant for the participant, according to how the latter relived it by discussing it. Both the events and phases were included in large categories, which can be applied to the group of trajectories analysed, according to the similarity or proximity between them. In order to facilitate reading, the analytical components present in the article will be indicated with the first letter in capital letters (e.g., Learning and waiting; Waiting for fate); definitions of the principals components can be consulted in Appendix 1. Once the categories of the events and phases were established, the linking of these, i.e., the succession of events and periods (or combination of same) making up trajectory 1 , trajectory 2, trajectory 3 was created, and carried out successively, covering the different specificities.

The final step consisted of comparing the trajectories described synthetically using the categories of events and phases, to create a final summary that contains the recurrent patterns in some categories of the Career Models of women in middle management positions. The diagram of analytical components emerging from the systematic analysis can be seen in Figure 1. As can be seen, there are two types of codes, first-level ones (applied directly to the data), and second-level ones (which are in bold as they are the result of the combination firstlevel codes). In this second group are the Transition Types, synthesis of the Transition Types and the Transition Events; and the Career Models, the outcome of the Transition Patterns and the Carrer Phases. It is worth mentioning that each of the Transition Patterns was formed by a central transition and different variations. Why each of these transition patterns is accompanied by a subindex (R,RE o A) depending on the nature of the change they point to, which may be Reactive, Reactive of Exploration or Active, respectively. That is, transitions to which they have been invited (Reactive); transitions to which they have been invited, have been explored but ended up declining (Reactive of Exploration); or transitions searched (Active). In turn, these subindexes are accompanied by + or to illustrate graphically the achievement $(+)$, or not $(-)$, of the transition event. In short, the following analytical diagram allowed to proceed in a systematic analysis of the stories that make up the body.

\section{Results}

The outcomes of the analysis are summarised in four career models. Each model is composed of certain types of career transitions and stages. 


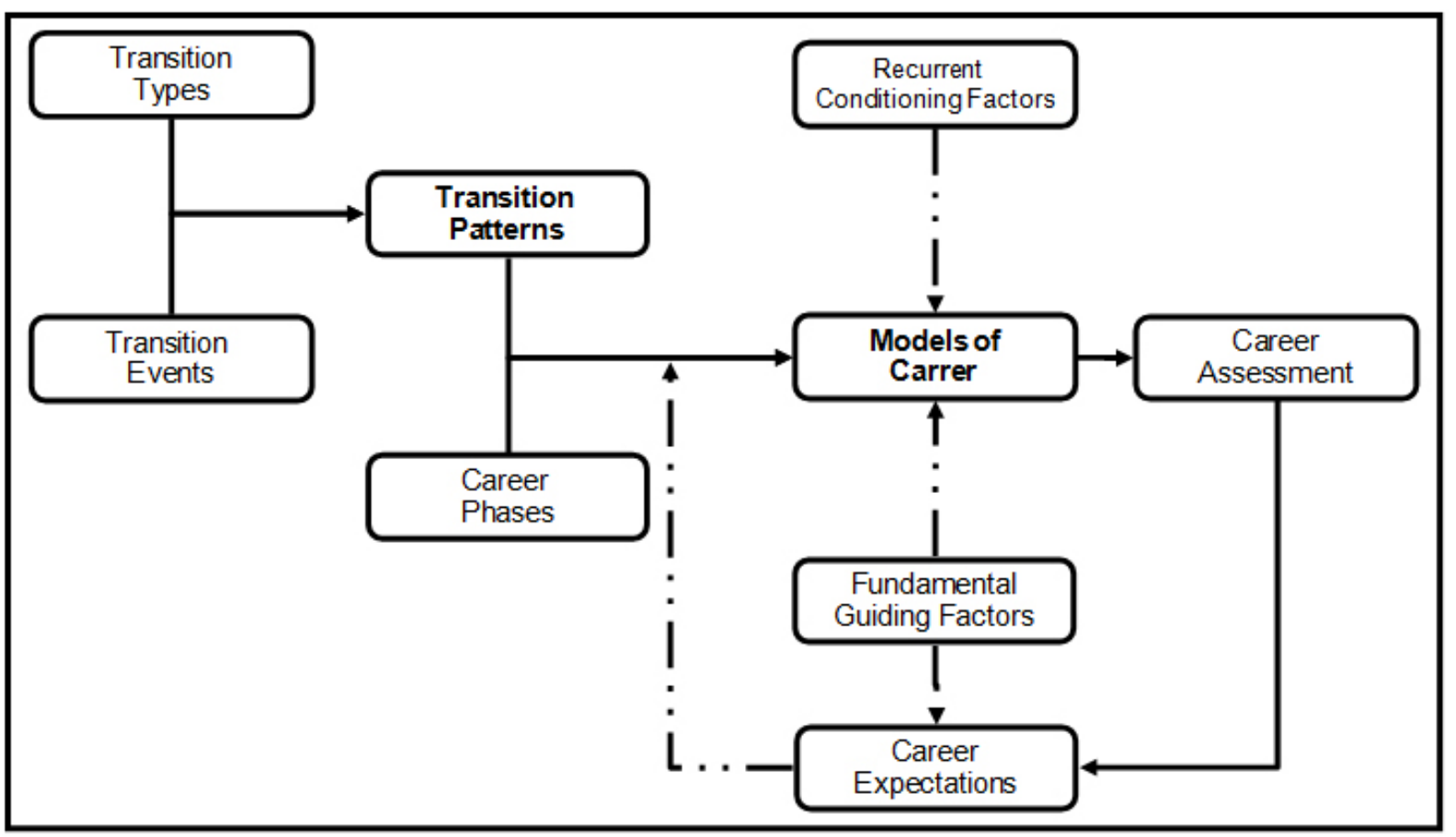

Figure 1. Analysis diagram: analytical components.

Source: Own work.

\section{Model 1. My life is in another place}

The main theme of the Model "My life is in another place" is that of wanting to reach, or having reached a management position, tasting it and deciding to take a step back. In other words, it is an ascending evolution of the professional trajectory until (for personal or family reasons) a backward step is taken. The common denominators of this model (Figure 2) are the Transition Patterns of Step forward, Relocalisation, Re-prioritisation and Step backward; combined with the career phases of Learning and waiting, Enduring, Parenthesis and Working and enjoying. These patterns and phases are combined in such a way that at the start the agent seeks to "make a trajectory" or not weigh up positions of responsibility (the phase Learning and waiting) and, once tried (after not being comfortable in the position or due to certain events in the person's personal life) they decide to take a step backwards, prioritising the personal and family life over the professional (which is accompanied by the Working and Enjoying phase).
The characteristic trait of this model is the search for personal and family fulfilment when making a decision. In other words, they are careers in which an effort is made to progress professionally, as long as this does not imply having to give up other aspects of the private life: "There is another part which is my personal life and it interests me more than my professional life and, therefore, if I had the opportunity to be promoted without having to give that up...I might consider it. If I had to give that up I wouldn't consider it" (Silvia, 1998) and "It's not the job I would most like. I like working in a hospital, but since it's not as easy to raise a family working hospital hours I adapted to working here (Cap Medical Centre)" (Claudia, 2010).

This woman is not willing to advance in her career at any price. She essentially avoids power (games): "I've never liked these positions. They have never been and are not my goal. But I did want to try it" (Claudia, 1998). This avoidance may lead to declining positions of responsibility offered to them, although they finally "taste" them, aware that the opportunity often only presents itself once: "They 


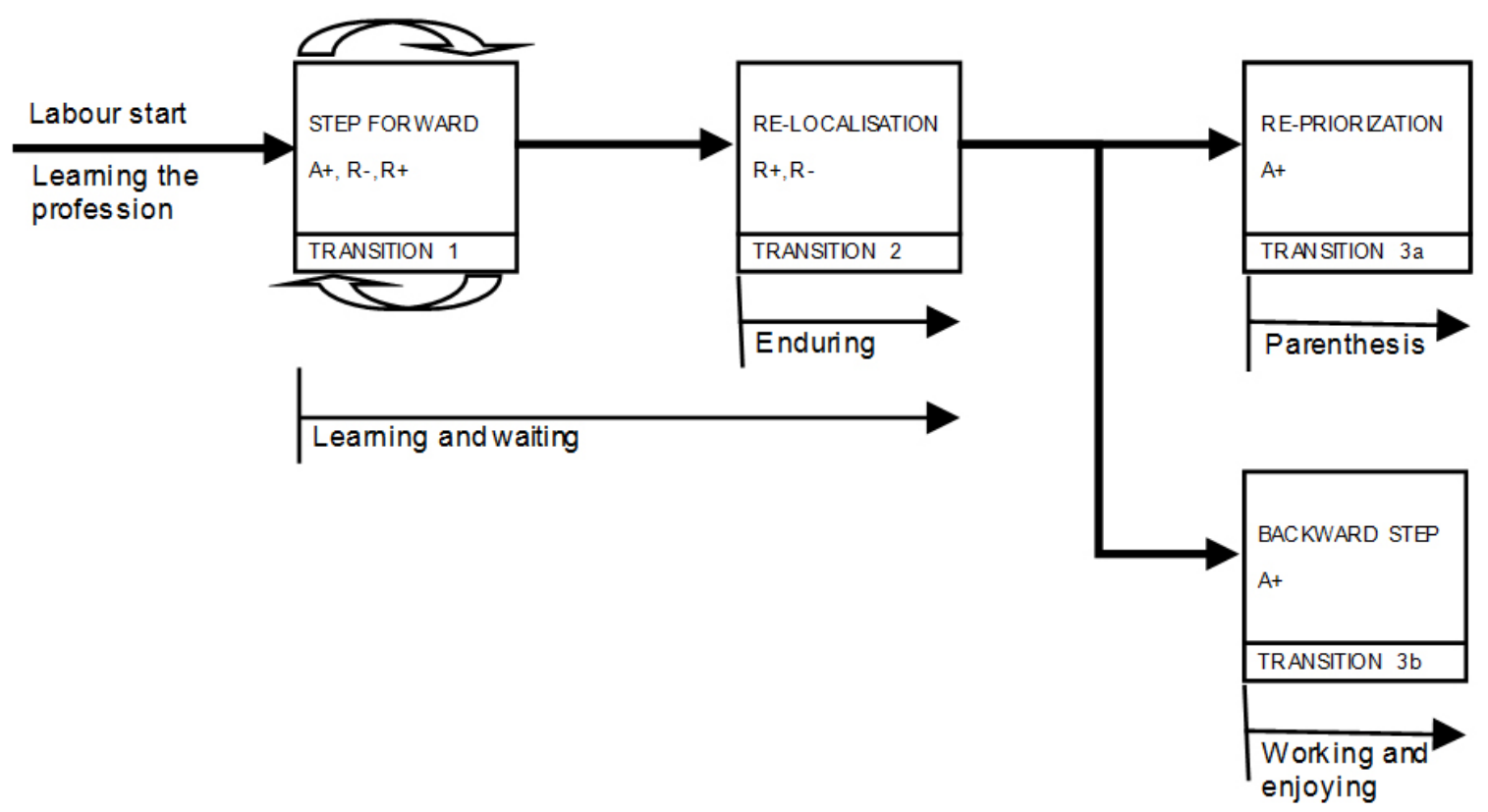

Figure 2. Basic diagram of Model 1. My life is in another place.

Source: Own work.

are positions that you can't always reach and maybe one day I would have been interested and I would never have known what it was..." (Claudia, 1998).

The lack of interest in these positions, the continuous search for a certain comfort (finding "my place") and the need to re-prioritise areas (as the result of certain events that have taken place in their personal life) mean that they voluntarily move towards positions of less responsibility: "When I accepted this position I said that in the long-term I didn't want to be a nurse manager, but that I wanted to have an ordinary nursing position" (Claudia, 2010) and "My husband died and I still had a young child so I decided that I couldn't maintain the same rhythm because it required an important level of involvement, so I requested a change" (Silvia, 2010). Backward steps are experienced as a type of liberation: "When I landed here it was like a sort of liberation, I could eat what I wanted, I could organise my life the way I wanted to"(Claudia, 2010) and "Now I am delighted" (Silvia, 2010); and enable them to organise their lives and look after their personal needs: "I don't want to change back to a management position because I have specific personal situations that I think would prevent me from doing it. I have a young daughter who is disabled (...) and takes priority. That is my reason for living" (Silvia, 2010).

\section{Model 2. Taking opportunities}

The main theme of the Model "Taking opportunities" is the desire to fulfil their professional expectations of reaching management, by means of overcoming new challenges presented to them. The trajectory can develop in one same organisation, taking the opportunities that may arise there; or by moving from one organisation to another, as a means of fulfilling their professional expectations. The common denominators of this model (Figure 3) are the Transition Patterns of Expansion; Turn: Step forward; Moving and reset; combined with the Career Phases of Parenthesis; Learning and waiting, Enduring and Working and enjoying. These patterns and phases are combined in one way or another, depending on the specific case. However, what remains constant is the fact that the initial phases of the trajectory tend to be associated with the Learning and waiting phases, while those of Working and enjoying tend only to occur when the desired position or career has been achieved. 


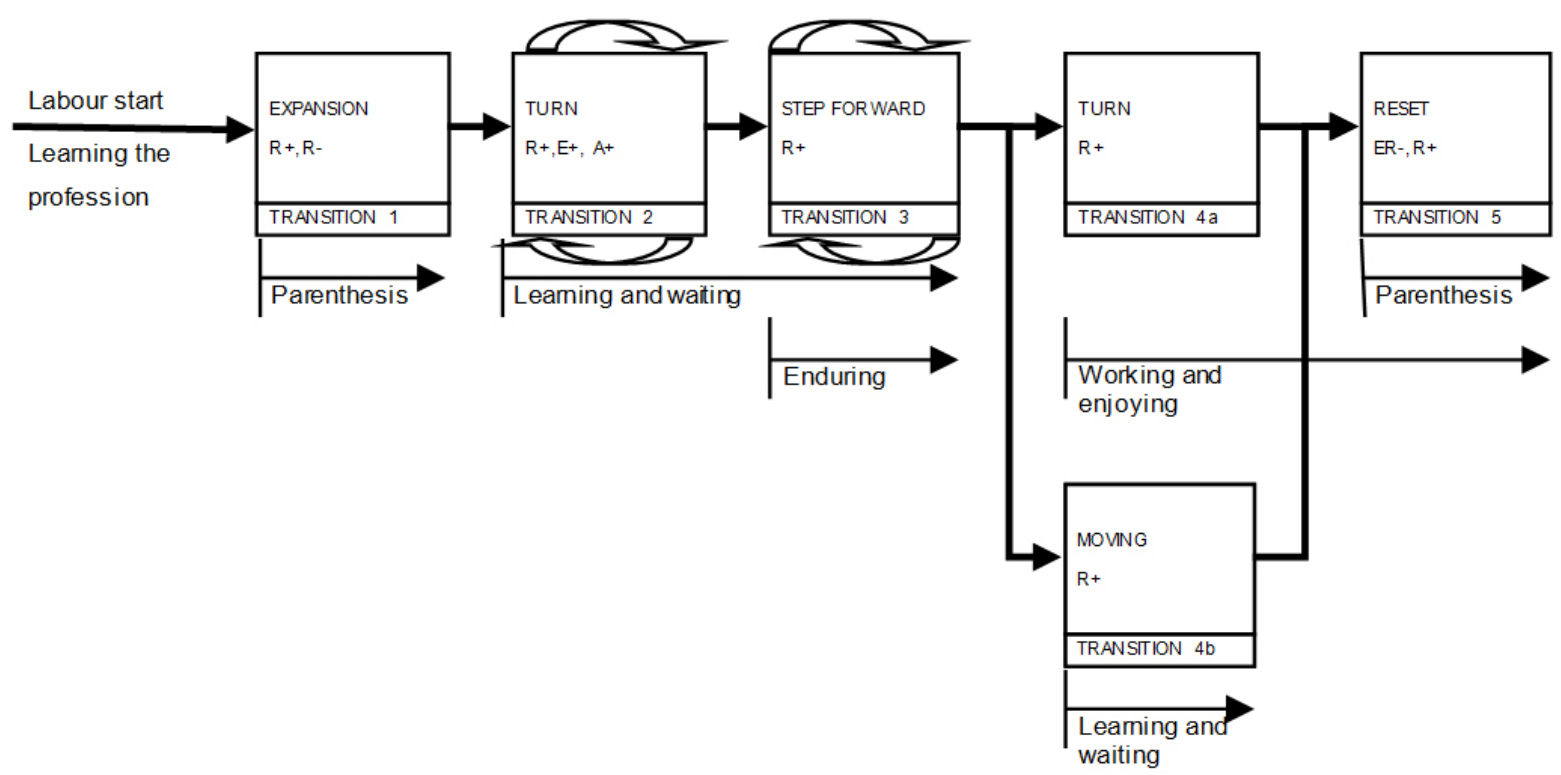

Figure 3. Basic diagram of model 2. Taking opportunities.

Source: Own work.

In order to advance in the professional trajectory: "To grow professionally, discover other experiences" (Monica, 2010), and to avoid work from becoming monotonous: "When you find yourself in those moments when either you find it very monotonous, or you have been there a long time already and you have no incentives...there have been periods of... until something appears, right? Something that helps you" (Marina, 2010); maintaining the same commitment and involvement as the first day: "I have been working for 30 years, and for 30 years I have seen clients. Every time I see a client I have the same feeling of attention as regards being prepared, doing things as I should, like on the first day" (Laia, 2010). To fulfil their expectations, the woman is constantly looking to learn; she focuses on continuing to learn from the positions she holds and makes the most of the training opportunities that arise during her career: "So my decision to do this was to increase my training, to gain more knowledge and to be a person with more overall knowledge as regards companies and different departments, to be able to apply for higher positions" (Monica, 2010).

They define their objectives and goals: "I set the limitations, the limitations of what I wanted to do" (Laia, 2010); and for the purposes of personal choices they prioritise their professional life over their personal life, so as not to give up their career: "There have been many times when if I compare myself to others, I have favoured my career, but it has always been a... I've always felt like it was worthwhile" (Laia, 2010). Choices that can generate feelings of resignation with the passing of time, as a result of not seeing certain personal desires fulfilled (such as becoming a mother again): "When I wanted a second child this project came up and it fulfilled me so much that I thought 'now is not the time, now is not the time' and we kept putting it aside. Now we are trying for a second child and it might be too late (...) Back then I preferred to prioritise my job and now I regret it" (Marina, 2010). In other words, the feeling of resignation is greater when they have not been able to fulfil the personal aspect as they would have liked, and that if they had done it, as other colleagues of theirs did, their professional trajectory would not have suffered that much.

When making decisions, although they strategically consider future possibilities: "I was worth more if I followed another trajectory, what Americans call your market value. You have a higher market value if you do certain jobs and even more so here (Spain) than if you have a more international job, because 
the market value doesn't...' (Laia, 2010). They don't have a plan of where they want to get to, i.e., it is more a desire to achieve certain challenges than to strictly plan the path to follow: "I have never been a person who plans a lot. I prefer to do what feels right at the time" and "I have ascended a lot in the past few years and I really like challenges so I have taken them on, but I never looked for them. That has meant that I have felt dizzy at times because l've thought, this is too big for me" (Marina, 2010).

What is most paradoxical is that although they want to fulfil their expectations, feel capable of doing it: "I'm quite versatile and I think that I can do it well" (Monica, 2010), and do continuous training, the majority of the transitions that characterise their trajectories are reactive; they wait to be invited/selected for certain positions that they find stimulating or that they consider applying for in their imagination. The progress of their trajectories is therefore explained by the presence of mentors: "They've always thought of me, I mean they've always thought of me and offered it to me. It's also true that I'm not difficult. I've always been interested" (Laia, 2010). Opportunities are offered to them and they "take" them. When these opportunities that they are waiting for do not arise or if they do, do not bear their name, although they feel disappointed for not receiving the recognition that they think they deserve, they seek the strategy that most coincides with the phase of life in which they find themselves; i.e. change organisation or work on the personal aspect: "I thought that I could be promoted, it wasn't for me (...) and so strategically from my personal point of view, I decided to have my son" (Marina, 2010).

\section{Model 3. Everything for the Organisation}

The main theme of the Model "Everything for the Organisation" is to be at the entire disposition of the organisation and its needs; accompanied by an attitude of constantly waiting for new opportunities or professional positions which the organisation (or in its absence the mentor) might invite them to take or might select them for. The common denominators of this model (Figure 4) are the Transition Patterns of Moving; Step forward; Turn; Re-localisation; Re-prioritisation and Backward step; combined with the Career Phases Learning the profession; Learning and waiting; Working and enjoying; Enduring and Parenthesis, giving rise to various compositions in which patterns and phases come together in different ways, depending on the

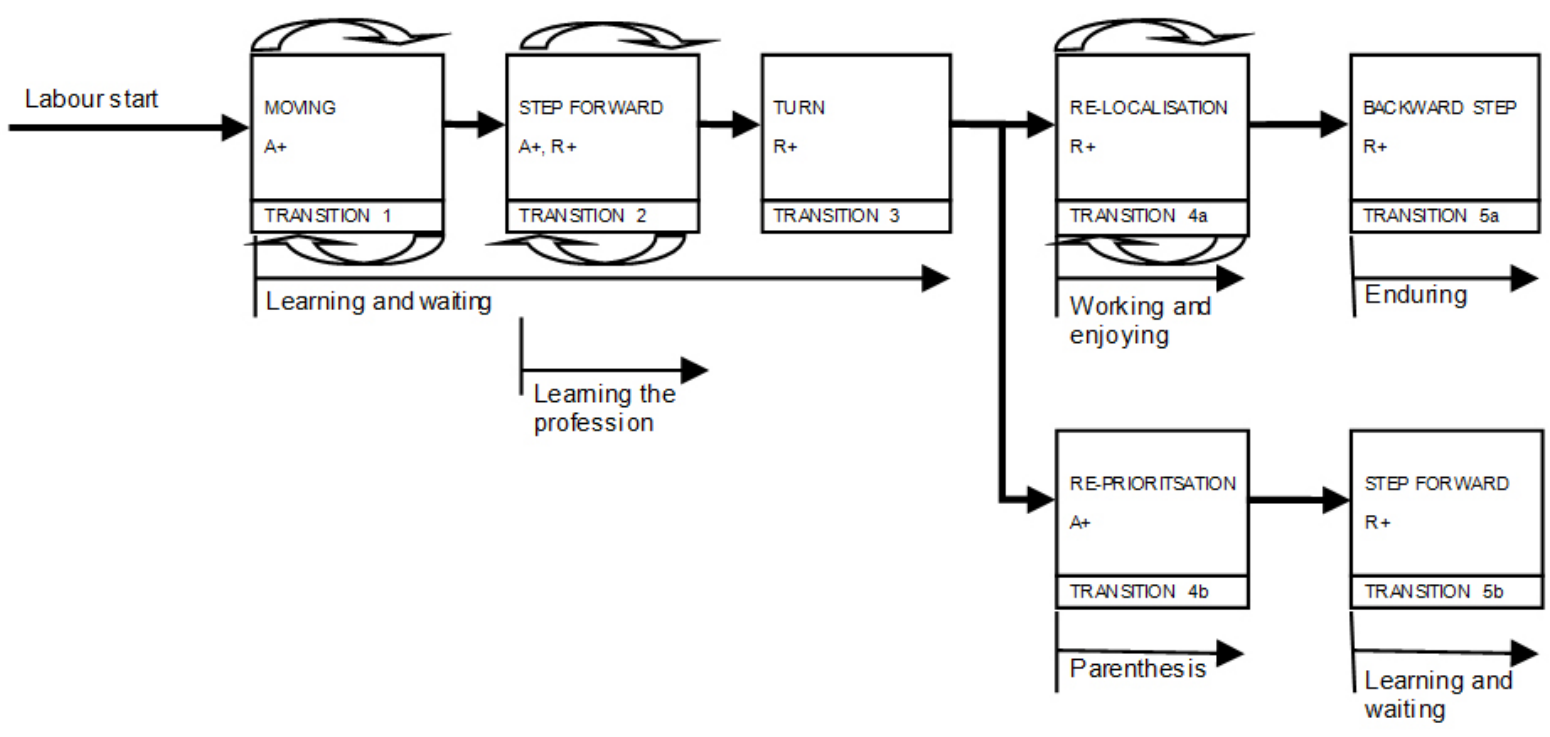

Figure 4. Basic diagram of model 3. Everything for the Organisation.

Source: Own work 
specific case. However, what remains consistent is that Moving always occurs at the start, before embarking on the professional trajectory that interests them.

A characteristic trait of this model is that although the agents start working in other companies, once they embark on their desired profession (see Learning the profession Career Phase in the glossary) the trajectory always evolves in the same organisation: "I entered here from a lower position" (Nuria, 1998), and "I've worked here for 20 years and it is the only company that I have known from the inside because it is where I started my professional trajectory" (Anna, 2010); producing an agent-organisation co-growth. This growth trend, combined with the agent's continuous learning and working attitude: "To know, to know everything" and "I'm a person who becomes very involved in work, I have shown that I am interested in what I am doing, I believe in the company and I have fulfilled what was set out for me" (Anna, 2010), have enabled her to develop very different roles, allowing her to become familiar with a varied organisational situation: "I started directly as an operator on a production line and I have learned how to assemble, weld, adjust" (Anna, 1998), and giving her visibility. These factors mean that (in a reiterative manner) she may be selected for new professional opportunities that appear: "Since I had moved around a lot and already had some knowledge and continued to move, it gave me the opportunity to continue moving, and then maybe they'd think: Anna has been in this project and she knows a bit of logistics... so she can go to logistics" (Anna, 2010).

The transitions characterising the Career Model "Everything for the Organisation" tend to be reactive, i.e., by invitation, except those at the beginning of the trajectory in which the agent's active nature can be observed: "I applied and I got the place (...) but the company was still growing and that is when I was offered the position, if I was interested" (Anna, 2010). The company decides, invites, brings about transfers or changes in position and facilitates places, giving rise to learning through which the trajectory can advance: "After several years I became the manager of the Vallès office, for a year, and then I became the area manager. From February onwards the company was restructured again and I was sent to other offices" (Nuria, 2010). All of these transitions, which often involve small steps forward, mean that woman is considered a leader in the organisation (due to her history and experience) and, therefore, she will be able to take on or develop new professional roles or projects, especially when these are new and/or occur in periods of change (crisis).

The woman responds to this trust in her and to the professional opportunities offered to her with a loyal and co-responsible work ethic as regards the organisation's objectives; attitudes that appear entirely natural when they refer to the company as "your house" in their accounts. These attitudes towards the organisation mean that at times when areas of life need to be re-prioritised (for example, the arrival of a child or the appearance of demanding family circumstances), they need to ask for approval: "I asked to not be on the front line for a few months, (...) they said to me: is here ok? You'll be here for a few months; and it was perfect (...) Later they asked me to go on the front line again and that is where I am now" (Anna, 2010); which they receive until the company decides that it is time for her to return to the role and the dedication that she had. The strong identification with the organisation explains how, when it proposes a change, which the agent is not expecting or does not want (such as reduced responsibility when her expectations are to reach a management position) the agent accepts it, in order to not disappoint the organisation (they consider it like a moral obligation): "At the start it's surprising. Because when you haven't asked for a change you wonder why you're being offered a change now" (Nuria, 2010). Although the change means a backward step in the trajectory (possibly with no return) the agent looks for the reasons in her own behaviour and/or work, and not in the organisation: "You always have the doubt that maybe you didn't do something the way they wanted you to, but I think you have to adapt to the company's needs (...) and so, at the start, I was a bit surprised but then I accepted it and I am doing it without any type of problem" (Nuria, 2010); and on account of the relationship with the organisation and her loyalty, she accepts the situation and sees it as something positive, adapting to it. 


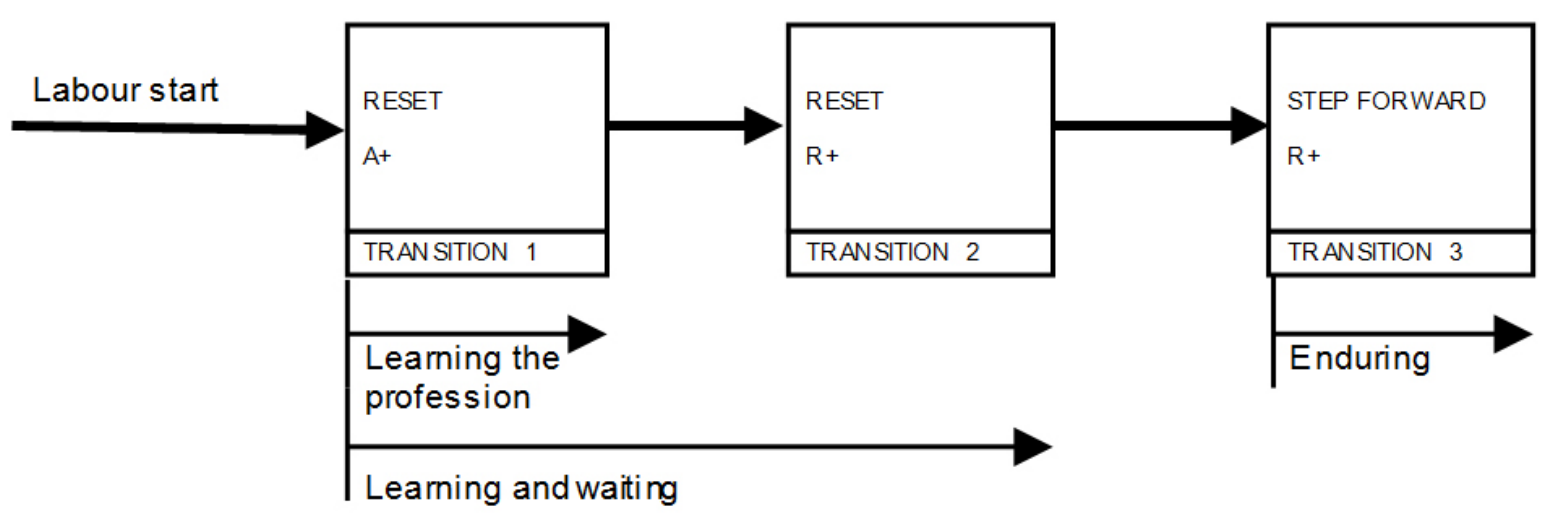

Figure 5. Basic diagram of model 4. Dead End.

Source: Own work.

\section{Model 4. Dead End}

The main theme of the Model "Dead End" is the stagnation (apparently with no way back) that occurs in the professional trajectory, as a result of a change in the organisation, giving rise to a feeling of profound frustration. The common denominators of this model (Figure 5) are the Transition Patterns Reset and Step Forward, combined with the Career Phases Learning the profession, Learning and waiting and Enduring. These patterns and phases come together in such a way that, at the start, the agent seeks to develop a professional trajectory (the phases Learning the profession and Learning and waiting), which, marked by certain Recurrent Conditioning Factors that bring the career to a halt, are later combined with the Career Phase of Enduring.

The characteristic trait of this model is the lack of direction, the uncertainty of not knowing where the professional trajectory is headed and the lack of direction of the same by the agent herself, which is caused by a change in her organisation: "That merger was very traumatic for everyone (...) because we were already starting as the ones who were losing out" (Miriam, 2010). This professional uncertainty is added to the absence of mentors (who guide, promote or act as coaches): "I have not managed to learn anything from my boss", a figure who is often blamed for her situation: "They haven't helped me at all, not him nor anyone. Because I was ready for this Service Unit and they didn't give it to me" (Miriam, 2010).
Other factors, often crucial in women's trajectories towards positions of responsibility, such as Waiting for fate or opportunities, have not played the role expected either: "If I was lucky I'd go somewhere else too. What happens is that you talk to people but noone knows you here. Here you're abandoned to fate" (Miriam, 2010). However, in her last account, the agent systematically rejects the networks of contacts (which often facilitate new professional opportunities): "They go for dinner once a week to get together...just the thought of having to go out with these numskulls who I don't know and put up with them for a whole evening" and the lack of external facilitators (chance, opportunities, mentors) strain their relations in the work environment: "Insult all day long. Yes, yes, the pipes vanish around here. I don't care" (Miriam, 2010). In general, her account is filled with a notable fatalistic tone: "...but I'll put up with it as long as I can. The outlook is really bad...", which in some cases is shared (if other colleagues also find themselves in a position of professional stagnation after changes the organisation has undergone): “... We've been very forgotten here, it's like another world. This is the jungle (...), it's a really nasty experience and it's a case of save yourself if you can" (Miriam, 2010). In this last case a more festered account is formed in which tunnel vision dominates (see the Career Phase Enduring in the glossary) which impedes the agent from seeing other ways out.

Thus, while the start of the professional trajectory is marked by changes in the sector in which 
the agent is less or more active (within public administration) and which respond to the desire to advance in her trajectory: "That's why I came. I left urban planning because I thought I would be better here" (Miriam, 2010), the present (after the aforementioned organisational changes) is characterised by a feeling of Enduring which makes them live their daily life with cynicism: "I laugh at myself here and I laugh at everyone else. I always say I'm a cleaner with a mop, which is always an advantage. The day they make me wash the floor on my knees I'll reconsider but in the meantime... it's shit" (Miriam, 2010).

\section{Discussion}

Women's accounts reveal some constant features in their professional trajectories, especially regarding management positions, and regardless the Career Model in which they find themselves. We discuss four constant features: a) a notable attitude of waiting for potential promotions - although they desire them; b) continuous learning as a fundamental direction in their career, on which they base the majority of their growth expectations and the need to demonstrate their worth; c) relating their professional trajectory as a result of external elements that have helped them to reach management; mentors, chance and perseverance; d) the lack of planning surrounding their promotions.

The action strategies present in their trajectories vary from one model to another, depending on the essence or central theme of each of these, i.e., while some involve continuously adapting to situations, accepting demands and organising areas (Everything for the Organisation) others are built around making themselves visible, accepting opportunities when these arise and organising their life according to the professional and promotion possibilities that may arise (Taking opportunities). Likewise, regarding the other two models, these respond to the quest for personal and/or family comfort and, therefore, to the re-prioritisation of areas (My life is in another place); or to promote the womens' independence in their trajectory, creating a more demanding and ambiguous situation since that type of self- management is interpreted as being on their own (Dead End). These action strategies influence the attaining of their professional expectations: of new positions, of obtaining a management position, of leaving the company or of being with the family. These expectations are paradoxical if we remember that there is no planning in her trajectories and that the transitions, for practical reasons (and aside from some action strategies of visibility), are expected (Gersick \& Kram, 2002).

Regarding compatibility they relate in that they have had no problems, since they do not differentiate between two spaces in their life sphere: the personal/family and professional areas, but rather, there is only one space in which they move around and simultaneously carry out their roles in alternation and in accordance with the precise needs of the situation. However, according to the model (which defines one or another type of relation with the organisation) explicit demands for compatibility are identified or they choose to look for satisfaction (looking after the personal or professional sphere more). With the passing of time, this quest for satisfaction may go hand by hand with feelings of resignation or loss for not having achieved everything they had desired in one area of life (we are referring to that area in which they did not seek satisfaction). It is surprising that in this compatibility of areas and time, only in one model (My life is in another place) are there accounts pointing to the desire to develop other activities (that are not part of the professional or family environment), such as studying English, which corresponds to the desire for personal growth.

Compared to men, using references from the literary corpus, the professional trajectories of women require the presence of external elements that facilitate their promotion. While for men being prepared is the key factor determining promotion, women also need the presence of a mentor. This, thus, shapes the trajectories in a zigzag, characterised not by personal action but by making the most of the opportunities that arise in their professional path (Gersick \& Kram, 2002; Selva, Tresserra, Pallarès, \& Sahagún, 2012). 
In the case of men, their trajectories are more linear, they take place in a field of action and build an ascending path in this over the course of time (Sterrett, 1999; Super, 1963, 1976), while the trajectories of women are explained by a combination of factors, among which appear context and aspects of their personal life, which are reflected in their professional situation (Felmlee, 1984; Sterrett, 1999). Therefore, it appears that the context of life and the actions that are taken in life are catalysts of the professional development of men and women (Omair, 2010; Selva et al., 2012).

\section{Conclusions}

The agents' accounts have contributed to the understanding of their professional and personal situations. In other words, the experience of their trajectories have revealed the elements that comprise them, the perception that they have and the strategies put into place to obtain their objectives (Evetts, 2000); all from the perspective of the meanings that render them intelligible for their protagonists. These accounts have led us to visualise Career Models as a means of analysing professional trajectories; models that can be applied to other fields and contexts.

That is, it will be interesting for future research to take these models as a guide for interpreting the careers, allowing, on the one hand, to validate them with a larger sample, including more moments of information gathering of female and male voices, and on the other hand, to contribute to the theoretical and conceptual development. In this regard, the contrast between career and gender will reveal the analytical factors which explain some Career Models and not others, will demonstrate the role of gender in accessing to positions of responsibility and will define the key elements that occur in the professional framework between women and men. In this scenario, the research of the decisions made and the career experienced are central to visualise how these courses and career choices are critically determined by the access to certain social, cultural and economic resources, and for being members of a society that confers different expectations for women and men. What is central to understand is why some professions and some positions within professions are still dominated by men. This, coupled with the application of the models to other work environments (in which may differ the personal, social and organisational factors put in play compared to the ones sighted in this study), will validate them, reformulate them or adapt them to other contextual characteristics.

In the present case, they have enabled us to analyse the trajectories from middle management to management (in public and private organisations) by means of the combination of Transition Patterns and Career Phases, as well as to analyse the key elements (of a personal, social and organisational nature), which condition some transitions and, therefore, some Career Models. We are referring to Fundamental Guiding Factors and Recurrent Conditioning Factors. It is an interpretation, which, by means of the experience lived and related - from the perspective of the meanings that render them intelligible for their protagonists-, provide the main theme to understand, conceptualise and differentiate the career models as well as their meaning.

\section{References}

Anca, C., \& Aragón, S. (2007). La mujer directiva en España: catalizadores e inhibidores en las decisiones de trayectoria profesional. Academia: Revista Latinoamericana de Administración, 38, 45-63.

Baron, R. A., \& Byrne, D. (2005). Prejuicio: causas, efectos y formas de contrarrestarlo. In R. A. Baron \& D. Byrnes (Eds.), Psicología social (pp. 215-261). Madrid: Prentice-Hall.

Berbel, S. (2013). Directivas y empresarias. Mujeres rompiendo el techo de cristal. Barcelona: Aresta Mujeres.

Boado, M. (1996). Movilidad ocupacional y mercado de trabajo: las caras ocultas del empleo urbano en Montevideo. Revista de Ciencias Sociales, 12, 23-35.

Bonilla, A., \& Martínez, I. (1992). Análisis del currículum oculto de los modelos sexistas. In M. Moreno (Coord.), Del silencio a la palabra. Coeducación y reforma educativa (pp. 60-92). Madrid: Ministerio de Asuntos Sociales, Instituto de la Mujer. 
Bourdieu, P. (1997). The forms of capital. In A. H. Halsey, H. Lauder, P. Brown \& A. -S. Wells (Eds.), Education: culture, economy and society (pp. 46-58). Oxford: Oxford University Press.

Buontempo, M. (2000). Inserción laboral de graduados universitarios: un estudio desde las trayectorias laborales. Corrientes, Ag: Universidad Nacional del Nordeste.

De Beauvior, S. (2000). El segundo sexo. Feminismos. Madrid: Ediciones Cátedra.

Dickman, A., \& Eagly, A. (2000). Stereotypes as dynamic constructs: Women and men of the past, present, and future. Personality and Social Psychology Bulletin, 26, 1171-1188.

Galindo, L. J. (1997). Sabor a ti. Metodología cualitativa en investigación social. México: Universidad Veracruzana.

Godoy, L., \& Mladinic, A. (2009). Estereotipos y roles de género en la evaluación laboral y personal de hombres y mujeres en cargos de dirección. Psykhe, 18(2), 51-64.

Eagly, A., \& Carli, L. (2007). Women and the labyrinth of leadership. Harvard Business Review, 85(9), 63-71.

Encyclopedia of Career Development. (2006). SAGE Publications. Available at http://sage-ereference. com/careerdevelopment/Article_n57.html

Evetts, J. (2000). Analysing change in women's careers: Culture, structure and action dimensions. Gender, Work and Organisational, 7(1), 57-67.

Felmlee, D. (1984). The dynamics of women's job mobility. Work and Occupations, 11(3), 259-281.

Fernández, N. (2002). El desarrollo profesional de los trabajadores como ventaja competitiva de las empresas. Available at http://dialnet.unirioja.es/servlet/ articulo? codigo $=309740$

Gersick, C., \& Kram, K. (2002). High achieving women at midlife: An exploratory study. Journal of Management Inquiry, 11(2), 104-127.

Hartl, K. (2004). The expatriate career transition and women managers' experiences. Women in Management Review, 19(1), 40-51.

Heilman, M. E. (2001). Description and prescription: How gender stereotypes prevent women's ascent up the organizational ladder. Journal of Social Issues, 57(4), 657-674.

Hola, E., \& Todaro, R. (1992). Los mecanismos del poder. Hombres y mujeres en la empresa moderna. Buenos Aires: GEL.
Jiménez, M. (2009). Tendencias y hallazgos en los estudios de trayectoria: una opción metodológica para clasificar el desarrollo laboral. Revista Electrónica de Investigación Educativa, 11(1), 1-21.

Kelan, E. (2009). Gender fatigue: The ideological dilemma of gender neutrality and discrimination in organizations. Canadian Journal of Administrative Sciences/Revue Canadienne des Sciences de l'Administration, 26(3), 197-210.

Latack, J. (1984). Career transitions within organizations: An exploratory study of work, nonwork and coping strategies. Organizational Behavior and $\mathrm{Hu}$ man Performance, 34(3), 296-322.

Linehan, M. (2000). Senior female international managers: Why so few? Ashgate: Aldershot.

López, M. (2007). Factores determinantes en el acceso de la mujer a puestos directivos. Capital Humano, 207, 84-93.

López, E., \& García-Retamero, R. (2009). Mujeres y liderazgo: idiscapacitadas para ejercer el liderazgo en el ámbito público? Feminismo/s, 13, 85-104.

Mallimaci, F., \& Giménez, V. (2006). Historias de vida y método biográfico. Estrategias de la investigación cualitativa. Barcelona: Gedisa.

Martínez, M., \& Pallarès, S. (2000). Dones en càrrecs de responsabilitat: des del comandament intermedi a l'alta direcció. Barcelona: Institut Català de la Dona.

Omair, K. (2010). Typology of career development for Arab women managers in the United Arab Emirates. Career Development International, 15(2), 121-143.

Pallarès, S., \& Martínez, M. (1993). Imágenes de la dirección: metáforas de la función directiva desde la propia dirección. Revista de Psicología, 4, 27-35.

Pratto, F., Stallworth, L. M., Sidanius, J., \& Siers, B. (1997). The gender gap in occupational role attainment: A social dominance approach. Journal of Personality and Social Psychology, 72, 37-53.

Ramos, A., Barberà, E., \& Sarrió, M. (2003). Mujeres directivas, espacio de poder y relaciones de género. Anuario de Psicologia, 34(2), 267-278.

Selva, C., Pallarès, S., \& Sahagún, M. A. (2013). iEntre obstáculos anda el camino? Trayectoria y mujer directiva. Revista de Psicología de las Organizaciones y el Trabajo, 13(1), 75-88.

Selva, C., Sahagún, M. A., \& Pallarès, S. (2011). Estudios sobre trayectoria profesional y acceso de la 
mujer a cargos directivos: un análisis bibliométrico. Revista de Psicología del Trabajo y de las Organizaciones, 27(3), 227-242.

Selva, C., Tresserra, O., Pallarès, S., \& Sahagún, M. A. (2012). El rio y el sendero como carreras profesionales: contrastando relatos con género. Quaderns de Psicologia, 14(1), 61-70.

Selva, C., \& Vitores, A. (2013, May). Gendered career trajectories pitfalls and challenges of the 'doing gender' approach. Working paper presented in The 5th Christina Conference on Gender Studies, University of Helsinky, Helsinky.

Simpson, R. (2000). Gender mix and organisational fit: How gender imbalance at different levels of the organisation impacts on women managers. Women in Management Review, 1(15), 5-19.
Sterrett, E. (1999). A comparison of women's and men's career transitions. Journal of Career Development, 25(4), 249-259.

Super, D. (1963). Career development: Self-concept theory. New York: College Entrance Examination Board.

Super, D. (1976). Career education and the meanings of work. Washington: U.S. Office of Eductation.

Tharenou, P. (1999). Gender differences in advancing to the top. International Journal of Management Reviews, 1(2), 111-132.

Wajcman, J. (1998). Like a man: Women and men in corporate management. Cambridge: Polity Press.

Wajcman, J., \& Martin, B. (2002). Narratives of identity in modern management: The corrosion of gender difference? Sociology, 36(4), 985-1002. 


\section{APPENDIX}

\section{Table A1}

\section{Glossary of analytical elements}

\section{Fundamental Guiding Factors (FGF)}

Adapting or leaving it

Waiting for fate

Being there for my organisation

Organising my life

Feeling comfortable

Being recognised

Recurrent Conditioning

Factors (RCF)
Continuous learning

Basic principles that guide the way the agent operates in the professional setting; they are the basis for making decisions and guide the relations and reactions established in the professional sphere.

Adapting to or agreeing with the role, fulfilling the circumstances and conditions in the organisation at a certain time.

Interpreting the professional trajectory in terms of trust, i.e., bestowing the element "chance" with the certainty that it will happen.

Feeling of being there for the organisation and for its needs as a response to the trust the organisation has placed in me.

The woman does not differentiate between two areas in her life: personal and professional. Rather, her life consists of one area in which she moves around.

Refers both to the agents' description of how they have experienced their trajectory, and the description of the experience of certain situations; i.e. it can be interpreted from a cynical perspective.

The predominant role training has for women is notable, in order to strengthen their professional development.

Refers to the well-being or comfort being in a certain position provides.

Involves considering oneself, or being recognised in the eyes of others, in terms of merit, talent, experience and know-how.

Aspects of the professional environment and private life that influence the formation of alternatives and decision-making, and which comprise the different phases of a professional career and its moments of transition.

Absence/presence of A catalyst that accelerates and forms possibilities of ascent (exercising guidance, promomentors ter and coach roles).

Avoiding power (games) Motivations that seek to satisfy the woman in the different positions that she holds during her trajectory: prioritising personal satisfaction over her professional position.

Phases differentiated according to what they have meant, in terms of profession and life, for the women who have experienced them.

Career Phases (CP) for the women who have experienced them.

Learning the profession when the profession was learned.

Learning and waiting Routines of learning and waiting which give order and stability to the professional life.

Attitudes of resistance or tolerance when faced with adverse professional situations Enduring which are solved by adapting to them or "jumping" to another position or moving companies.

Parenthesis Refers to periods characterised by their professional instability or irregularity; it is a waiting period.

Working and Enjoying

Notable for the work routines, the associated feelings of fruition and for holding positions that provide comfort and satisfaction in both the professional and private life.

Combination of

Transition Events (TE2)

Combination of transition events which, together with transitions, form Transition Patterns.

Active actions Active actions by the agent; i.e. changes that she requests or seeks.

Reactive actions the woman is selected. 
Exploratory Reactive Reactive actions (proposed) which the woman explores or weighs up; although she deactions clines them in the end.

Transition Patterns (TP) Configurations or combinations of transition events and types of transition (change); the product of a combination.

Expansion Composed of Reactive TE2 and combined with transitions involving the expansion of functions.

Turn Composed of Reactive and Active TE2 which are combined with transitions involving a change in roles.

Moves Composed of Reactive and Active TE2 which are combined with transitions involving changing companies (moving).

Re-localisation Composed of Reactive TE2 which is combined with transitions involving re-localisation (as regards the factory or office where the agent works).

Re-prioritisation Composed of Active TE2 which is combined with transitions involving a change in priorities (as regards personal-family life).

Backward step Composed of Reactive and Active TE2 combined with transitions involving reduced responsibilities.

Reset Composed of Reactive, Exploratory Reactive and Active TE2 which are combined with transitions involving a jump between sectors; i.e., a change in the professional sector.

Forward step Composed of Reactive, Exploratory Reactive and Active TE2 combined with transitions involving an increase in responsibility.

Career Models (CM) Refer analytically to less or more recurrent combinations of transition patterns and career phases. 